Creative Commons User License: CC BY-NC-ND

Abstracted by: EBSCOhost, Electronic Journals Service (EJS),

Google Scholar, Journal Seek, Scientific Commons,

Food and Agricultural Organization (FAO), CABI and Scopus

http://eoi.citefactor.org/10.11226/v24i4
Journal of Agricultural Extension

Vol. 24 (4) October, 2020

ISSN(e): 24086851; ISSN(Print); 1119944X

http://journal.aesonnigeria.org

http://www.ajol.info/index.php/iae

Email: editorinchief@aesonnigeria.org

\title{
Factors Influencing Adoption of Sustainable Soil and Water Conservation Practices among Smallholder Farmers in Kwara State, Nigeria
}

https://dx.doi.org/10.4314/jae.v24i4.12

\section{Iyilade, Abigail Oluwatunmise}

Women and Youth Development Division, Department of Rural Development and Gender Issues, Agricultural and Rural Management Training Institute (ARMTI), llorin, Nigeria.

iyiladeabigail@gmail.com ,+2347032027493

\section{Alalade, Oluwasegun Ayodeji}

Extension Management Division, Department of Rural Development and Gender Issues (RUDEG), Agricultural and Rural Management Training Institute (ARMTI), llorin, Nigeria.

segunalalade@gmail.com ,Phone: +2347063880416

\section{Longe, Morenike Peju}

Extension Management Division, Department of Rural Development and Gender Issues (RUDEG), Agricultural and Rural Management Training Institute (ARMTI), llorin, Nigeria.

onikoyipeju@yahoo.com ,Phone: +2348037631394

\author{
Alokan Agnes Olubunmi \\ Department of Agricultural Extension and Economics, National Agricultural Extension and Research \\ Liaison Services, Ahmadu Bello University, Zaria. \\ agnesslopez@yahoo.com, ,+2348038029532
}

\section{Akinola-soji Blessing}

Nigeria Stored Product Research Institute (NSPRI), Ilorin, Nigeria.

blessingakines@gmail.com ,+2348069347968

\section{Abstract}

The study examined the factors influencing the adoption of soil and water conservation practices (SWCPS) among smallholder farmers in Kwara State, Nigeria. Multi-stage sampling procedure was used to select 210 farmers. Farmers were surveyed for their adoption of eleven (11) SWCPS, and risk factors and costs of production. Poisson regression model was employed to estimate soil and water conservation practices adoption. Sex, access to credit, land acquisition, technical support, ownership of livestock, distance to input/market, marital status and formal trainings had a significant relationship with the number of soil and water conservation practices adopted by smallholder farmers $(P \leq 0.01)$. Some personal and demographic factors, institutional factors, as well as socio-economic factors have a significant relationship with soils and water conservation practices adopted by farmers. Agricultural policies should be geared towards helping smallholder farmers have access to extension service for frequent dissemination of agricultural technology as this will increase the rate of adoption of soil and water conservation practices. 
Creative Commons User License: CC BY-NC-ND

Abstracted by: EBSCOhost, Electronic Journals Service (EJS), Google Scholar, Journal Seek, Scientific Commons,

Food and Agricultural Organization (FAO), CABI and Scopus

http://eoi.citefactor.org/10.11226/v24i4
Journal of Agricultural Extension

Vol. 24 (4) October, 2020

ISSN(e): 24086851; ISSN(Print); 1119944X

http://journal.aesonnigeria.org

http://www.ajol.info/index.php/iae

Email: editorinchief@aesonnigeria.org

Keywords: Adoption, Soil and water conservation techniques; smallholder farmers, Kwara State,

\section{Introduction}

Soil and water resources are critical resources necessary for life and survival. Less than 3 percent of all water on earth is non-saline, fresh water suitable for human consumption (Kilders, 2015). However, over 75 percent of this is locked away as ice in glaciers and polar icecaps with the balance found in underground aquifers, surface waters, and soil moisture (Kilders, 2015). Therefore, protecting soil and water resources against degradation is vital for continued productivity and food production for human-kind, provision of regenerative ecosystem services, and maintenance of biodiverse landscapes. Through time, the expansion of human populations has led to the alteration of natural landscapes into urban settlements, agricultural systems (crops and livestock grazing) for food production, and harvest of natural resources (timber, minerals) to satisfy ever-increasing demand for resources.

Additionally, soil erosion is a natural process occurring on every landscape (Blanco and Lal, 2018). Physical forces (wind, water, and disturbance by animals and cultivation) and biogeochemical forces (chemical weathering) work together to create a highly dynamic system of soil formation, plant growth, nutrient replenishment and depletion, and loss of soil materials due to erosion. Vegetation contributes root biomass and facilitates the formation and maintenance of soil biotic communities, which increase soil organic matter volume, supports soil structure, and increases water infiltration rates (Krishna, Bicol, Ingrid, and Giridhari, 2018). These factors support the maintenance of cohesive soil structure, and decomposition of large particulate organic matter into important soil nutrients. These nutrients are then available for vegetative growth. Furthermore, natural soil fertility is maintained by a complex interaction of the aforementioned with climate, soil biota, and biogeochemical cycles.

Mucavele (2015) reports that most of the smallholder farmers in sub-Saharan Africa have not stopped practicing traditional methods of farming such as land clearance poor farming practices, overgrazing, inappropriate irrigation, land pollution including industrial waste. These and many more are the primary causes of land degradation in the region. Majority of the smallholder farmers still employ least developed inputs in their farming activities instead of integrating modern soil and water conservation technologies. Mango et. al., (2017) state that the shortage of variation in farming systems intensifies glitches of degradation of land, water and soil resources which results in soil fertility problems and therefore have a negative effect on agriculture.

Degradation of the soil results in the weakening of soil quality which lessens the productivity of the soil. This, therefore, jeopardizes the sustainability of agriculture, the quality, and stability of the environment and further has an adverse effect on the economic and social development of the nation. Without taking the necessary soil and water conservation practices, the cost of tackling soil degradation will increase and productivity will continually reduce, hence influencing revenues generated from 
Creative Commons User License: CC BY-NC-ND

Abstracted by: EBSCOhost, Electronic Journals Service (EJS), Google Scholar, Journal Seek, Scientific Commons,

Food and Agricultural Organization (FAO), CABI and Scopus

http://eoi.citefactor.org/10.11226/v24i4
Journal of Agricultural Extension

Vol. 24 (4) October, 2020

ISSN(e): 24086851; ISSN(Print); 1119944X

http://journal.aesonnigeria.org

http://www.ajol.info/index.php/iae

Email: editorinchief@aesonnigeria.org

exporting agricultural products as well as causing a rise in food insecurity for most people in sub-Saharan Africa.

According to Ajayi (2017), adoption of land, soil and water conservation practices has become a key concern in the development policy agenda for Sub-Saharan Africa. The adoption of land, soil, and water conservation practices that comprise mulching, intercropping, etc. has been considered as part of the agenda of agricultural development policy (Mango et. al., 2017). Presently in Kwara State, most of the modern SWCPs being disseminated by the extension agents under the ADP arrangement include: terrace farming, avoidance of overgrazing, ridging across the slopes, building dams, alternate planting of different crops in strips, application of organic manure to the soil amongst others. However, there is still low adoption rate of some of these sustainable agricultural practices in the State (Ajayi, 2017).

It is no longer possible to ignore the impact of depletion of soil and water resources that has led to the deterioration and loss of resources. Although the issues of soil and water conservation have been subject to extensive research worldwide, few have examined the factors that influence the adoption of soil and water conservation practices in the study area. In this study, the soil and water conservation practices used comprise of row planting, intercropping, terrace farming composting, cover crops, crop rotation, intercropping, mulching, ridging across the slopes, building dams, alternate planting of different crops in strips, and manure. It is against this background that this study was designed to specifically examine factors influencing soil and water conservation practices and the factors influencing adoption of SWCPS in the study area.

\section{Methodology}

The study was conducted in Kwara State, Nigeria. The state which lies between latitudes $7^{\circ} 45^{\prime} \mathrm{N}$ and $9^{\circ} 30^{\prime} \mathrm{N}$ and longitudes $2^{\circ} 30^{\prime} \mathrm{E}$ and $6^{\circ} 25^{\prime} \mathrm{E}$ has two distinct seasons (the wet and dry seasons). Kwara state has 16 local government areas (LGAs). The state is classified into four (4) agricultural zones - A, B, C and D based on their agronomic uniqueness.

A multi-stage stratified random sampling procedure was employed in the selection of zones, blocks, cells and villages for the study. The first stage involved a random selection of Zone A and D of Kwara ADP administrative zone. Thereafter, random sampling of two (2) LGAs each from the two chosen ADP zones was implemented in the second stage, making a total of four (4) LGAs. In the third stage, random selection of 2 communities from each of the 4 LGAs selected in the second stage was carried out. Hence, a total of 8 communities were sampled. In the last stage, the farm families' population provided by ADP was utilized (Table 1) to select a sample size of 218 for the state using proportion allocation technique. By this technique, the number of sampled farming households was obtained such that 
Creative Commons User License: CC BY-NC-ND

Abstracted by: EBSCOhost, Electronic Journals Service (EJS), Google Scholar, Journal Seek, Scientific Commons,

Food and Agricultural Organization (FAO), CABI and Scopus

http://eoi.citefactor.org/10.11226/v24i4
Journal of Agricultural Extension

Vol. 24 (4) October, 2020

ISSN(e): 24086851; ISSN(Print); 1119944X

http://journal.aesonnigeria.org

http://www.ajol.info/index.php/iae

Email: editorinchief@aesonnigeria.org

\section{Where;}

$\mathrm{n}_{\mathrm{h}}=$ Number of farming households to be selected in stratum/zone $\mathrm{h}$

$\mathrm{n}=$ Total number of sampled farming households

$\mathrm{N}_{\mathrm{h}}=$ Number of farming household population in zone or stratum $\mathrm{h}$

$\mathrm{N}=$ Total number of farming household population

Poisson regression model was used to determine the most significant factors that influenced the adoption of sustainable soil and water conservation practices among smallholder farmers in Kwara State. The Poisson regression is represented by the basic equation:

$P_{r}\left(y_{i} / x_{i}\right)=e^{-\lambda \lambda y} / y !, i=0,1,2$

where $\operatorname{Pr}(y i / x i)$ is the probability of farmer

$i$ adopting $y$ practices at a time and

$\lambda i$ is the Poisson parameter for farmer $i$.

Given that the expected number of SWC practices adopted per period is $E(y \mid x i)$, then the mean parameter as the function of the regressor, $x i$ and a parameter vector $\beta$ is given by:

$\varepsilon\left(y_{i} / x_{i}\right)=\lambda=\exp \left(x^{1} \beta\right)$

Where;

$\exp \left(x^{1} \beta\right)=\exp \left(\beta_{o}\right)+\exp \left(\beta_{1} x_{1}\right)+\exp \left(\beta_{2} x_{2}\right)+\cdots+\exp \left(\beta_{k} x_{k}\right)$.

The parameter $\lambda$ is assumed to be log-linearly related to repressor's $x_{i}$. therefore,

$\ln (\lambda)=\beta x_{i}$

The log-likelihood function is given by:

$\sum_{i=1,2_{m, n} n}\left[-\lambda_{i}+y_{i} \beta x_{i}-\operatorname{Iny} y_{i} !\right]$.

Where;

$y$ is the number of technologies adopted;

$\beta$ is a ixk vector of parameters;

$\mathrm{x}$ is a kxi vector with the values of $\mathrm{k}$ independent variables in the $i^{\text {th }}$ observation and $\mathrm{n}$ is the number of observations. 
Creative Commons User License: CC BY-NC-ND

Abstracted by: EBSCOhost, Electronic Journals Service (EJS),

Google Scholar, Journal Seek, Scientific Commons,

Food and Agricultural Organization (FAO), CABI and Scopus

http://eoi.citefactor.org/10.11226/v24i4
Journal of Agricultural Extension

Vol. 24 (4) October, 2020

ISSN(e): 24086851; ISSN(Print); 1119944X

http://journal.aesonnigeria.org

http://www.ajol.info/index.php/iae

Email: editorinchief@aesonnigeria.org

Table 1: Population and sample of smallholder farmers in Kwara State Agricultural Development Programme

\begin{tabular}{lllll}
\hline Zone & LGAs & $\begin{array}{l}\text { Communities } \\
\text { selected }\end{array}$ & $\begin{array}{l}\text { Smallholder } \\
\text { farmers' } \\
\text { population }\end{array}$ & $\begin{array}{l}\text { Number } \\
\text { respondents } \\
\text { selected }\end{array}$ \\
\hline A & Kaiama & Gwanabe & 2,090 & 31 \\
& & Kaiama & 1,517 & 23 \\
& Baruten & Okuta & 1,901 & 29 \\
& & Chikanda & 1,115 & 17 \\
D & Ifelodun & Igbaja & 2,235 & 34 \\
& & Omupo & 2,022 & 30 \\
& Irepodun & Esie & 1,645 & 25 \\
& & Ajasse-ipo & 1,928 & 29 \\
Total & & & $\mathbf{1 4 , 8 0 3}$ & $\mathbf{2 1 8}$ \\
\hline
\end{tabular}

Source: KWADP Survey, (2016)

\section{Results and Discussion}

\section{Characteristics of Respondents}

Table 1 reveals that the average farm size per farmer is about 4 acres. about $40 \%$ of the respondents get income from other sources aside farming. Also, few of the farmers had contact with extension agents during the crop season (29\%). The average household size per farmer is about 9 members and the average distance from the farmer's farm to the market or input store is $5 \mathrm{Km}$. For the method of land acquisition, only about $21 \%$ acquire land by gift, while $79 \%$ acquired land by rent or purchase. The average cost of labour per farmer is about $\$ 1,750$ (USD 4.87). About $29 \%$ of the respondents own livestock and $38 \%$ have attended one form of training or the other while $48 \%$ admitted their farm lands are sloppy and steep. 
Creative Commons User License: CC BY-NC-ND

Abstracted by: EBSCOhost, Electronic Journals Service (EJS),

Google Scholar, Journal Seek, Scientific Commons,

Food and Agricultural Organization (FAO), CABI and Scopus

http://eoi.citefactor.org/10.11226/v24i4
Journal of Agricultural Extension

Vol. 24 (4) October, 2020

ISSN(e): 24086851; ISSN(Print); 1119944X

http://journal.aesonnigeria.org

http://www.ajol.info/index.php/iae

Email: editorinchief@aesonnigeria.org

\section{Table 2: Characteristics of small holder farmers}

\begin{tabular}{|c|c|c|c|}
\hline Variable & Description & Mean & $\begin{array}{l}\text { Std. } \\
\text { Dev. }\end{array}$ \\
\hline Soil and & Number of SWCP adopted & 1.87 & 1.51 \\
\hline \multicolumn{4}{|l|}{ Conservation } \\
\hline & & & \\
\hline Household size & Number of people & 8.75 & 4.91 \\
\hline Technical support & $\begin{array}{l}\text { Number of visits by extension agents } \\
\text { (per year) }\end{array}$ & 0.29 & 0.46 \\
\hline Age & Number of years & 49.76 & 6.48 \\
\hline Farm size & In acres & 3.97 & 1.99 \\
\hline Off-farm income & Dummy $($ No $=0 ;$ Yes = 1) & 0.41 & 0.53 \\
\hline Land acquisition & Dummy (gifted $=1$; otherwise $=0$ ) & 0.21 & 0.39 \\
\hline $\begin{array}{l}\text { Distance to input } \\
\text { store/market }\end{array}$ & In Kilometres & 4.82 & 2.28 \\
\hline Own livestock & Dummy $($ No $=0 ;$ Yes $=1)$ & 0.29 & 0.35 \\
\hline Labour cost & In Naira per year & 1750 & 3502.50 \\
\hline Training & Number of Trainings attended & 0.38 & 0.41 \\
\hline Topography & How steep the slope of the farm land is & 0.48 & 0.76 \\
\hline
\end{tabular}

Source: Field Survey, 2020

\section{Factors Influencing Adoption of Sustainable Soil and Water Conservation Practices}

Table 2 reveals a pseudo $R$-square of 0.40 (Chi square $=0.0001 ; P \leq 0.05$ ), implying that all the variables together described the number of SWCPs adopted in the study area. The variables that were found to be significant include gender $(\beta=0.8022$; $z$ value $=3.78)$, training $(\beta=-1.3902$; $z$-value $=-2.03)$, marital status $(\beta=1.0202$; $z$ value $=4.31)$, access to credit $(\beta=1.3011 ; z$-value $=5.29)$, technical support $(\beta=$ 0.3672 ; z-value $=3.02)$, distance to input store and market $(\beta=1.0202 ; z$-value $=$ 1.82), livestock ownership $(\beta=0.4799$; $z$-value $=2.68)$, and land acquisition $(\beta=$ $0.8979 ; z$-value $\left.=3.62^{* * *} ; \mathrm{P} \leq 0.05\right)$. The result shows that there is a direct relationship between each of these variables and the number of practices adopted.

Table 2 further reveals a significantly positive relationship between gender and number of SWCPs adopted by the respondents. The result implied that male farmers are more likely to adopt modern agricultural innovations than their female counterparts. The result is consistent with the findings of Abdallah (2017) who reported that male farmers are more likely to adopt agricultural production techniques than their female counterparts. This however contradicts the findings of James and Ngala, (2015) that showed gender does not affect adoption. The result could be attributed to the fact that men are the ones who make production decisions and control productive resources such as land, labour, and capital which are critical for technology adoption. 
Creative Commons User License: CC BY-NC-ND

Abstracted by: EBSCOhost, Electronic Journals Service (EJS), Google Scholar, Journal Seek, Scientific Commons,

Food and Agricultural Organization (FAO), CABI and Scopus

http://eoi.citefactor.org/10.11226/v24i4
Journal of Agricultural Extension

Vol. 24 (4) October, 2020

ISSN(e): 24086851; ISSN(Print); 1119944X

http://journal.aesonnigeria.org

http://www.ajol.info/index.php/iae

Email: editorinchief@aesonnigeria.org

Access to credit was found to have a positive and significant association with the number of soil and water conservation practices adopted by the farmers $(\beta=1.3011$; $z$-value $=5.29$ ). The result underscores the importance of providing farmers with credit to support their investment in productive activities. This is consistent with the findings of Eneyew, Alemu, Ayana, and Dananto, (2015) that adoption of manure and mineral fertiliser is associated with farmers who had access to off-farm income. Abdul-Hanan, Ayamga, and Donkoh, (2017) reported that farmers who have access to credit are mostly motivated to adopt any modern technology as compared to farmers who are constrained by lack of capital.

Table 2 also reveals that married farmers $(\beta=1.0202$; $z$-value $=4.31)$ have a higher probability of adopting SWCPs than their single counterparts. This is because couples do not only serve as a supplement for labour but also create a platform for searching and sharing of ideas about techniques. It was therefore expected that married farmers will adopt soil and water conservation practices than their unmarried counterparts. Also, training of farmers was among the institutional factors found to have a positive and significant relationship with the number of soil and water conservation practices adopted by the farmers $(\beta=-1.3902$; $z$-value $=-2.03)$. This finding is consistent with a study carried out by Kwasi, Joana, Frank, and Daniel, (2019) who identified that training has a positive association with the adoption of sustainable soil and water conservation practices. Therefore, training of farmers is a means of creating awareness and encouragement for the adoption of modern technologies.

Distance to input market is consistent with our expectation as it was hypothesised to be negatively related to the intensity of adoption of soil and water conservation measures. This implies that farmers whose farms are far from the input store/market have a lower probability of adopting soil and water conservation practices. This finding is consistent with a study carried out by Abdul-Hanan et. al., (2017) on smallholder adoption of soil and water conservation techniques in Ghana who concluded in support of this finding. Their findings found that the closer a farmer's farm was to the input store, the more the adoption of SWCPs. This finding is consistent with a study carried out by Teklewold, Kassie, and Shiferaw (2015) who concluded in support of this finding. Their findings identified that the means of transportation to output market is associated with the likelihood of adoption of improved seed and conservation tillage. The nearness of a farm to an input store does not only motivate the farmer to purchase the input, but it minimizes the transportation cost of conveying the input to the farmer's house. It can therefore be concluded that distance from input store/market is a crucial factor for the individual soil and water conservation decision.

Livestock ownership $\left(\beta=0.4799\right.$; $z$-value $\left.=2.68^{\star \star *} ; P \leq 0.05\right)$ was also significantly and positively related to number of SWCPs adopted per farmer. It is worth noting that livestock ownership is a proxy variable for wealth and power. It was expected that household with wealth and power will have higher probability of adopting the technologies than their poor counterparts. The result is consistent with that of Ayamga and Dzanku (2015) who explained that households' resources help to either 
Creative Commons User License: CC BY-NC-ND

Abstracted by: EBSCOhost, Electronic Journals Service (EJS), Google Scholar, Journal Seek, Scientific Commons,

Food and Agricultural Organization (FAO), CABI and Scopus

http://eoi.citefactor.org/10.11226/v24i4
Journal of Agricultural Extension

Vol. 24 (4) October, 2020

ISSN(e): 24086851; ISSN(Print); 1119944X

http://journal.aesonnigeria.org

http://www.ajol.info/index.php/iae

Email: editorinchief@aesonnigeria.org

invest to maintain soil or further enhance the productivity. The level of technical support provided to farmers in terms of the number of visits by extension staff, was significantly related to the adoption of SWCPs by farmers $(\beta=0.3672$; $z$-value $=$ $\left.3.02^{\star * *} ; \mathrm{P} \leq 0.05\right)$. Abdul-Hanan et. al., (2017) found that farmers' contact alone with extension officers will not enhance the adoption of modern technology if services of extension officers such as information dissemination on modern technology are ineffective and inaccurate. Ayamga and Dzanku (2015) observed that farmers who do not receive frequent visits from extension officers have lower likelihoods of adapting to modern technology as compared to farmers who are visited frequently.

Table 2: Factors influencing soil and water conservation practices

\begin{tabular}{llll}
\hline Variable & Coefficient & Std. err. & Z \\
\hline Constant & -1.4315 & 0.5321 & $-2.32^{* *}$ \\
Age & -0.0006 & 0.0109 & -0.06 \\
Gender & 0.8022 & 0.1923 & $3.78^{\star * *}$ \\
Farm size & 0.0321 & 0.0324 & 0.79 \\
Household size & -0.0048 & 0.0123 & -0.42 \\
Education & -0.0089 & 0.0345 & -0.29 \\
Training & -1.3902 & 0.5123 & $-2.03^{* *}$ \\
Marital status & 1.0202 & 0.2312 & $4.31^{* * *}$ \\
Credit access & 1.3011 & 0.2391 & $5.29^{\star * *}$ \\
Off-farm income & -0.1132 & 0.2100 & -0.56 \\
Land acquisition & 0.8979 & 0.2491 & $3.62^{* * *}$ \\
Distance to input store/market & -0.0719 & 0.0313 & $-1.82^{*}$ \\
Group membership & -0.0301 & 0.1987 & -0.32 \\
Labour cost & -0.0001 & 0.0001 & -0.52 \\
Own livestock & 0.4799 & 0.2410 & $2.68^{* * *}$ \\
Off-farm income & -0.1035 & 0.2142 & -0.51 \\
Technical support & 0.3672 & 0.3011 & $3.02^{* * *}$ \\
Topography & -0.0814 & 0.0344 & $-1.76^{*}$ \\
Number of observations & 218 & & \\
LR chi-square & 142.35 & & \\
Probability chi-square & 0.0000 & & \\
Pseudo R & 0.4023 & & \\
Variance inflation factor & 3.1032 & & \\
\hline
\end{tabular}

\section{- P $\leq$ 0.05. Source: Field Survey, 2020}

\section{Conclusion and Recommendations}

Sex, and formal training; access to credit, access to extension services, distance to input market, topography; land acquisition, number of livestock owned have a significant relationship with soil and water conservation practices adopted by farmers. Providing farmers with credit access will enable them to meet the cost involved in the initial stages of adoption thereby increasing production. To increase 
Creative Commons User License: CC BY-NC-ND

Abstracted by: EBSCOhost, Electronic Journals Service (EJS), Google Scholar, Journal Seek, Scientific Commons,

Food and Agricultural Organization (FAO), CABI and Scopus

http://eoi.citefactor.org/10.11226/v24i4
Journal of Agricultural Extension

Vol. 24 (4) October, 2020

ISSN(e): 24086851; ISSN(Print); 1119944X

http://journal.aesonnigeria.org

http://www.ajol.info/index.php/iae

Email: editorinchief@aesonnigeria.org

the probability of the adoption, agricultural practitioners should mobilize smallholder farmers and train them for successful implementation of conservation practices.

\section{References}

Abdallah A. (2017). Determinants of adoption of soil and water and conservation techniques: evidence from Northern Ghana. Int. J. Sustainable Agricultural Management and Informatics, Vol. 3, No. 1, 2017.

Abdul-Hanan, A., Ayamga, M., \& Donkoh, S. A. (2017). Smallholder adoption of soil and water conservation techniques in Ghana. African Journal of Agricultural Research, (5), 539-546.

Ajayi, O. C. (2017). User acceptability of sustainable soil fertility technologies: Lessons from farmers' knowledge, attitude and practice in southern Africa. Journal of Sustainable Agriculture, 30(3), 21e40.

Ayamga, M. and Dzanku, F. (2015). The land rights and farm investment Ghana: The missing link in the operationalisation of tenure security, International Conference of the African Association of Agricultural Economists, Hammamet, Tunisia, pp.1-22.

Blanco, H. and R. Lal (2018). Soil and water conservation. Principles of soil conservation and management, Springer, the Netherlands.

Eneyew, A., Alemu, E., Ayana, M. and Dananto, M. (2015). The role of small scale irrigation in poverty reduction', Journal of Development and Agricultural Economics, Vol. 6, No. 1, pp.1221.

James, P. H. \& Ngala, A. L. (2015). Farmers' awareness, preference and adoption of soil conservation practices in Zing Local Government Area of Taraba State, Nigeria. Journal of Biology, Agriculture and Healthcare, 5(11), 1-5.

Kilders, L. (2015). http://conservationdistrict.org/2015/the-power-of-araindrop. html. Accessed on $13^{\text {th }}$ November 2019.

Kwara Agricultural Development Project (2016) Agronomic Survey Report for 2006 Cropping Season Planning Monitoring and Evaluation Department.

Mango, N., Makate, C., Tamene, L., Mponela, P., \& Ndengu, G. (2017). Awareness and adoption of land, soil and water conservation practices in the Chinyanja Triangle, Southern Africa. International Soil and Water Conservation Research, 5(2), 122 - 129.

Mucavele, F. G. (2015). True contribution of agriculture to economic growth and poverty reduction. A synthesis report. Malawi, Mozambique and Zambia.

Krishna, R., Bicol, K., Ingrid, I. and Giridhari, S. (2018). Determinants of farmers adoption of improved soil conservation technology in a Middle Mountain Watershed of Central Nepal. Environmental Management, Springer, New York.

Kwasi A.D, Joana D. K, Frank A. T, Daniel B. S. (2019). Assessment of the determinants that influence the adoption of sustainable soil and water conservation practices in Techiman Municipality of Ghana. International Soil and Water Conservation Research 7 (2019) 248257.

Teklewold, H., Kassie, M., \& Shiferaw, B. (2015). Adoption of multiple sustainable agricultural practices in rural Ethiopia. Journal of Agricultural Economics, 64(3), 597-623. 